\title{
Public space and memories of migration: erasing diversity through urban redevelopment in France
}

\author{
Roza Tchoukaleyska \\ City Institute, York University \\ $7^{\text {th }}$ floor, Kaneff Tower \\ 4700 Keele Street \\ Toronto, ON, M3J ${ }_{1} \mathrm{P}_{3}$ \\ Canada \\ rozatcho@yorku.ca
}

\begin{abstract}
This article examines the meaning of public space and impact of heritage-led urban redevelopment in a diverse neighbourhood in Montpellier, France. It traces the relocation of a North African market from a central city plaza in favour of French antiques, and the resulting contestation over what constitutes local heritage, who has the capacity to determine how public space is used, and the seeming erasure of migrant identities and memories from an important community plaza. The paper considers how urban areas are re-imagined through a change in the materiality of public space, and outlines the role of outdoor markets in defining the social function of such spaces. The paper examines the intertwining of physical erasure (urban redevelopment and the removal of a diverse food market) and cultural erasure (the loss of certain community memories), and how these processes speak to broader debates about French national identity, cultural heritage, and the meanings attached to public spaces.
\end{abstract}

Key words: public space, memory, identity, urban redevelopment, cultures of consumption, France

The ability to appropriate space, to write oneself into the urban fabric and carve out a visible presence in the city is a key step in establishing a viable, recognized, and enduring sense of civic belonging (Lefebvre, 1996). Alternatively, an inability to establish such a presence can lead to a sense of exclusion from the city (Ross, 1996) and from public space (Mitchell, 2003), and see the erasure of certain cultural identities, histories, and social existence from the urban realm. This paper takes these topics as the starting point for considering how cultural identities and linked consumption practices are inscribed in public spaces, and the ways in which alterations to the urban fabric can imperil those existences.

My examination of these topics has been focused on the southern French city of Montpellier where an ambitious €250-million urban redevelopment program has actively sought to alter the networks of urban streets, plazas, and parks that make up the city-center. The impact of this process has been most keenly felt in what might seem an unlikely context: the relocation of a diverse outdoor food market from the city's Plan Cabanes plaza, and its replacement by a municipally-created 
antiques and used books market in the late 2000s. A key node for Montpellier's North African community since the 1970s, the Plan Cabanes plaza and its outdoor market had been the commercial and social focal point of a larger neighbourhood network of halal bakeries, cafes, diverse shops, a mosque, tea houses, and restaurants that drew visitors from across the city. The shift of the outdoor market from the Plan Cabanes plaza to a nearby parking lot has been contentious, not least for being couched in a vocabulary of protecting French heritage and re-valorizing city-centre spaces.

With immigration increasingly labelled as problematic in France (Dikeç, 2007), and concentrations of what is perceived as ethnic 'difference' viewed with some suspicion (Simon, 2003), the relocation of a nominally North African food market in favour of antiques has become highly politicized. Some community groups have argued that through this redevelopment process North African identities - and by extension, memories of migration and resettlement - have been erased from a key public space in Montpellier, and the urban landscape purposefully re-ordered to reflect a homogeneous vision of French heritage and history. Others have challenged these assertions, and supported municipal efforts to redevelop the Plan Cabanes plaza. This has resulted in a divisive public debate that, many years after the initial market relocation, continues to circulate through the neighbourhood. The relocation of the diverse market from the Plan Cabanes plaza has become a proxy for wider questions about what constitutes local heritage, and who has the capacity to determine how public space is used.

In the pages that follow I will examine the importance of public space to memories of migration and the role of cultures of consumption in sustaining those memories. I will also consider the impact of large-scale urban redevelopment projects on the ability of diverse groups to sustain a viable and visible presence in the city. Drawing on the vocabulary deployed by Klein (1997), I trace the intertwining of physical erasure (removal of the outdoor food market from Plan Cabanes) and cultural erasure (the loss of certain community memories), and how they speak to broader debates about French national identity, cultural heritage, and the meanings attached to urban public spaces. This approach extends discussions on heritage dissonance (Hoskins, 2007; Carter et al., 2004) and the erasure of diversity in commemorative processes (Alderman \& Inwood, 2013) to a French context. I first consider the interplay between memory, heritage, and public space, before drawing on the findings of a year-long ethnographic study in Montpellier to consider the importance of the Plan Cabanes to remembrance, the effects of redevelopment on community spaces, and the resulting process of erasing diversity from the urban landscape.

\section{Remembrance, memory, and urban landscapes:}

My understanding of the term heritage, and its links with memory, have been influenced by O'Keeffe's (2007) discussion on the topic. For O'Keeffe, personal memories are emotional and sensual: the sounds, senses, and fragrances which shaped a particular experience, or what Proust (1913) might describe as an 'involuntary memory' spurred by the tasting of a madeleine. Historical memory, 
for O'Keeffe, is visual and factual and revolves around "things of which we are reminded"(2007, p.5) through the media, books, and formal accounts of events. This form of memory can be viewed as collective (Halbwachs, 1992), and while being shared by a wider audience it shapes what might be called 'heritage', or, the traditions, memories, and places which are held as culturally and socially relevant by a particular community. Heritage is a contested term, not least for questions of what constitutes heritage, and how collective and personal memories intersect with this concept (Wertsch, 2009). Yet it is also a useful analytic viewpoint for understanding how cultural identities are formed and linked to the materialities of urban landscapes (Rose-Redwood, 2008). By deploying the term 'collective memory' in the pages that follow, I am drawing on O'Keeffe's (2007) distinction between personal memory (what individual participants remember) and historical memory (how they situate these into broader narratives), all the while conscious that these two categories are not always so easily separated.

This interplay between the ways in which the city is perceived, conceptualized and lived (Lefebvre, 1991) and the role of remembrance and forgetting is echoed by Amin and Thrift who remind us that "a city named in certain ways also becomes that city through the practices of people in response to the labels"(2002, p.23). This is true of Blokland's (2009) findings in New Haven, Connecticut, where an Italian-American community group vies for attention with a local heritage protection association, each hosting a festival representing competing visions of local identity. Hidden in the subtle tussle between the two groups are the memories of low-income residents, whose stories of social dislocation are absent from these celebrations of neighbourhood identity. The result is a truncated vision of who forms the local community that, following Hoelscher and Alderman (2004), has reverberations for the capacity of all residents to be recognized as political, economic and social actors. As Jurgens argues, public memory is "implicated in political struggles not only over what defines legitimate knowledge of the past, but also over who and what defines the terms of collective membership" (2012, p.194). The way we remember the past is therefore central to our understanding of the present (Lowenthal, 1985), and through this, local historical narratives are linked to an ability to enact a political voice and to being recognized as a member of the broader urban community (Chivallon, 2001; Peckham, 2003).

The notion that memory and place-making are central to forming a shared identity is a point also outlined in Till's (2005) work on heritage and memory in Berlin. Examining Berlin's layers of conflict, trauma, triumph, and remembrance, Till (2005) alternates between personal narratives on the meaning of individual locations, such as metro stops and chain-link fences, and discussion of broader urban regeneration agendas. While urban planners view Berlin's city centre as an 'empty' landscape in need of redesign, discussions with residents reveal a rich history and complex memory processes of remembering and forgetting tied to these so-termed 'empty' lots (Till, 2005). What for developers appears as a new city holds, for East and West Berliners alike, memories of Cold War buildings, the shadow of the Wall, and Gestapo ruins unearthed as digging starts for high-rise 
buildings (Cochrane, 2006).

The attachment of stories to the seemingly banal fences, metro stops, and ruins of Berlin's city-centre are a form of vernacular memory (Muzaini, 2013) that challenge broader state visions of this city's history. They create a form of heritage dissonance (Hoskins, 2007) that complicates public memory - that socio-historical entity that Lowenthal (1985) relates to the creation of a national consciousness and identity - and in turn, alters how urban landscapes are understood. The destruction of such sites through regeneration processes creates hauntings (Edensor, 2008), leaving behind wisps of the political and social milieu that has been knocked down (Mansvelt, 2010; Lai, 2012). As Hayden (1997, p.9) notes, "when the urban landscape is battered, important collective memories are obliterated", thereby challenging the fabric of identity and history which shapes the city.

Disputes over whose memories are represented in the city, and how they are materially shown, are particularly acute when local visions of history and memory are brought into tension with national policies on heritage protection (Harvey, 2014). While for Bonnet and Alexander (2013) heritage protection policies can have transformative and affirming effects for communities, Waterton and Smith (2010) note that in other instances, national heritage policies can leave little room for diverse readings of neighbourhood landscape. As Ashworth and Tunbridge (1999) note, there is rarely an agreement on the meaning of heritage, with state commemorative processes frequently appropriating local narratives to bolster political goals.

\section{Public space and French collective memory:}

In France, these tensions between local and national visions of heritage take on a further dimension through the way that heritage and protection measures are conceptualized. For Gravari-Barbaras and Veschambre (2000) heritage is a social and political construction, one that Poirrier (2003) ties to French nation building, and which Stora (2003) suggests is based on an assumption of a stable, coherent, republican identity. Emerging in post-revolutionary France, heritage protection measures are geared towards maintaining physical urban and natural landscapes, and the social and cultural milieu which surrounds them (Linossier et al., 2004). Such measures encompass not only facades , monuments, and buildings, but also street culture, public space uses, and social activities. Gillot et al. (2013) argue that this process of identifying both places and cultural practices as patrimoine (heritage) has led to a process of patrimonialization, or an instance in which "heritage is used as a resource to achieve certain social goals" (Poria \& Ashworth, 2009). This brings heritage firmly into the public sphere and identifies public space as a key site for debates around what constitutes heritage, whose memories are encapsulated in protection policies, and what political discourses are given prominence in urban renewal programs.

For Nora (1989) memory is a conscious event that is linked to what he identifies as lieux de mémoire (realms of memory), or the physical monuments, museums, 
books, object, but also celebrations and parades and grand personas, which prompt individual citizens to take part in collective recognition of a defined national past. In Nora's (1989) lexicon, the 'personal memories' and 'collective memories' distinguished by O'Keeffe (2007) collide: personal memories are linked to collective memories through the ritual of public remembrance and interaction with spaces, objects, and ideas dedicated to eliciting an emotionalsensual reaction. Nora's (1989) lieux de mémoire illustrate the transmission of culture through the creation of spaces that embody national memory and determine what (and whom) is forgotten and erased, and dropped from the collectivity of what it means to be French. In this, the state is seen as having a key role in building and perpetuating such lieux de mémoire. The state also has a hand in deciding which events and objects are elevated to the status of 'collective memory'. As Buck-Morss argues, the transmission of culture:

is a political act of the highest import - not because culture in itself has the power to change the given, but because historical memory affects decisively the collective, political will for change (1989, p.xi).

The city, then, is as much an imagined space as a civic space, and the embedding of certain histories in the landscape has wide ranging repercussions for the capacity of diverse users to claim rights to the city (Lefebvre, 1996; Mitchell, 2003).

While Nora's (1989) work is in many ways a cornerstone for understanding the links between memory, heritage policies, and urban landscapes, it is also notable for some key absences. For Legg (2005) the conceptualization of lieux de mémoire fails to recognize that monuments can have different meanings for different viewers, and does little to challenge the visions of a unified, coherent, and homogeneous reading of French history. For Enjelvin and Korac-Kakabadse (2012), the absence of colonial heritage and memories of migration in Nora's (1989) work is mirrored by the erasure of these histories from formal heritage protection policies, and in turn, from many urban landscapes. Seeing current French heritage movements caught in a 'war of memories' over colonization and its modern histories, Stevens (2007), Stora (2003) and Veschambre (2007), have argued for a need to diversify the stories told and the range of images represented in heritage areas, museums, and written accounts of history (cf Amiraux \& Simon, 2006). As Melé (2005) has outlined in a detailed account of French heritage movements, such processes could lend themselves particularly well to building consensus around new visions of French identity (Benhamou, 2014).

The tensions surrounding the redevelopment of Montpellier's Plan Cabanes plaza are imbued in these larger debates on the meaning of French heritage, the (non)recognition of memories of migration, and a growing call for the need to broaden the meaning of patrimoine. The contested nature of Plan Cabanes redevelopment, and in particular the relocation of a diverse North African food market in favour of French antiques, is part of a poignant debate over the history, memory, and story assigned to the space. Being able to claim to hold the 'true' history of the plaza would, arguably, give some leverage to being able to shape its 
current form and usage. In that sense the stories and memories of plaza users are central to understanding how community is defined and what this space means to the diversity of neighbourhood residents.

\section{Setting the context:}

Situated in south-central France, Montpellier is the $8^{\text {th }}$ largest and one of the fastest growing cities in the country, and has an economy based on high-tech research, viticulture, tourism, research and tertiary education. Montpellier's medieval centre is surrounded by $19^{\text {th }}$ century faubourg (inner suburbs), and extensive post-1950s suburban high-rise neighbourhoods. The Plan Cabanes is one of Montpellier's older faubourg, with the neighbourhood's two-storey houses and their large bays for farm carts speaking to the area's agricultural origins. The plaza itself has hosted a produce market since the inter-war period, and from the 1970s onwards became an important reception area for migrants arriving from North Africa (Besombes-Vailhe 1995). This saw a shift in residential patterns, and a change in the food market itself with a greater diversity of foods, household goods, and personal items first appearing in the 1980s, and surrounding halal shops, tea houses, and restaurants into the 1990s (Faure, 1998).

Although municipally-led urban renovation has been a constant in Montpellier for several decades, the Plan Cabanes neighbourhood received limited attention until more recently. The establishment of the $€ 250$-million Mission Grant Coeur program in 2002 saw considerable funds dedicated to redeveloping the faubourgs, with the Plan Cabanes and its plaza featured prominently amongst them. The program has seen the application of faubourg-wide heritageprotection rules around façade renovations, coordinating street furniture, pedestrianizing retail streets, and protecting $19^{\text {th }}$ century architectural features, with the express goal of harmonizing these areas with the city-centre (Barone, 2010). As part of this program, the Plan Cabanes market was relocated from its name-sake plaza to a nearby parking lot in 2005 to allow for tarmac refurbishment. While market vendors were initially promised a return to the Plan Cabanes, in 2007 city council voted to formally transfer the produce market out of the plaza, and establish a new antiques, bric-a-brac and used book market in its place.

[Figure 1 about here]

The findings presented in this paper are based on ten-months of ethnographic, with two month-long follow up periods, that included spending market days in the Plan Cabanes neighbourhood, the antiques market, and the relocated food market. Ethnographic work was coupled with 21 semi-structured interviews with market vendors, municipal actors, local business people and representatives from community associations, as well as several weeks of work in the municipal archives to collate documents on urban redevelopment, market relocation, and the application of heritage policies. With Plan Cabanes vendors and local residents I frequently drew on a further research technique: talking-while- 
walking (Anderson, 2004; Degen \& Rose, 2012), during which research participants led me on a walking tour of their neighbourhood, and described the histories of buildings, and their personal memories of living and working in the Plan Cabanes. Interviews were conducted in French, and have been translated to English by the author, with pseudonyms used throughout.

\section{Neighbourhood memories:}

Understanding the Plan Cabanes' relevance, and the impact of the food market's relocation, means tracing a zig-zag of personal memories and disparate visions of local heritage through the neighbourhood. For some residents the Plan Cabanes is about the outdoor markets and the neighbourhood's retail history, others emphasize local $19^{\text {th }}$ century heritage and the city's links to French history more broadly, while some community groups view the plaza and surrounding streets as sites that encapsulate personal memories of migration and resettlement. The memories linked with the Plan Cabanes and surroundings are complex, and as might perhaps be expected, residents are often in disagreement about which element of the neighbourhood's history should be recognized through heritage protection measures. The stories I re-tell below are overlapping and not always linear, and form the sort of 'narrative economies' that Hoskins (2010) and Carter et al. (2014) identify as relevant to place making and identity building.

Sitting in a café across from the Plan Cabanes, Fabien, now in his mid-80s, points out a multi-storey sandy coloured building at the north end of the plaza. This, he explains, used to be the head office of the Salins du Midi, a company with a franchise to harvest sea-salt in the region. For Fabien this building stands out as the anchor of the plaza, a symbol of the area's commercial function. He sees incredible value in the municipal redevelopment project, not least because the Salins building has been sand-blasted and taken on the golden-yellow colour he remembers from childhood. For Juju, who used to help stallholders set up their market stands in the 1950s and 1960s, the plaza is wrapped up in memories of the pre-dawn noise of stalls being assembled, the bistros and cafes for breakfast. Juju tells stories of a farmer who kept livestock nearby and sold the milk in the market, and the vineyards which once started just a kilometer from the Plan Cabanes. Like Fabien, Juju emphasizes the retail role of the Plan Cabanes, and describes the plaza as a node for the span of streets, shops, and bistros to the west and south of the plaza. In our conversations he frequently described the plaza and its market as a "ghost" - a place that is part of Montpellier, but grudgingly, a seeking to hold onto an identity that distinguishes it from the historic city-centre. When I ask Juju about what heritage might mean, he explains that it does not exist anymore. Once the Plan Cabanes was renovated and the market moved, the links between the plaza and the surrounding neighbourhood were broken and the things worth remembering are, in his view, already gone.

Amongst the vendors who worked in the pre-relocation Plan Cabanes market there are several who had inherited their stands from parents and grandparents. They tell stories of the 1970 and 1980 s in the market plaza: small time farmers bringing 
in surplus, the rain in winter and winds in spring, camaraderie, profits to be made, a busy plaza. In the 1980s, one produce stallholder explained, the Plan Cabanes market began to change with the arrival of a diversity of new vendors and the beginnings of a North African commercial cluster in the neighbourhood. A pair of second-generation vendors describe the Plan Cabanes market of this period as expansive, stretching into the surrounding streets, and note the appearance of tea houses, new butcher shops and bakeries, and informal vendors around Ramadan. By the late-1980s you could heard Arabic and Berber alongside French, and with cafes' tables bordering vendors' stalls the market taking on a more social function. Many point out that certain aspects of the Plan Cabanes market, such as a low wall on one edge of the plaza where people could sit, meant that you could hang about and socialize. Many of the stallholders who were in the Plan Cabanes during the 2005 relocation were second- and third-generation vendors who had formed a closed-knit, if still competitive, working relationship. They view the relocation of the market as a profound break: for some, one that promised the revival of a smaller produce market mimicking the farmers' market that existed in the plaza in the 1970s; for others, the move from the Plan Cabanes is an uncomfortable shift that dislocated not only long standing market relationships but also personal memories of family, childhoods, and livelihoods in the plaza.

Others emphasize the $19^{\text {th }}$ and $20^{\text {th }}$ century military history that seeps through this area. Several residents have come together to form community associations that seek to commemorate this aspect of the Plan Cabanes: just south of the plaza is the site of a former city barracks, to the south-east of the Plan Cabanes are the 'streets of the Generals', named after Montpellier-born military figures who came to prominence during the Revolutionary and Napoleonic wars. Some of the local association members I met were keen to emphasize this, arguing that the Plan Cabanes was key not only to Montpellier's defence and military might, but to France more broadly. Napoléon's father had once lived nearby, and the city was home to several prestigious military colleges. During a walk through the neighbourhood one association member noted that these histories link the Plan Cabanes with the types of narratives told in school books and documentaries. Some of these neighbourhood associations actively work with the municipality on heritage protection plans and engage in public meeting, produce newsletters and booklets, and during research interviews highlighted the street signs and plaques which commemorate the military heritage of the area. For Azaryahu such formal signage is "a component of French political symbolism" (1996, p.313), and coalesces around the sorts of symbols Nora (1989) identified as central to institutionalized remembrance. It is also a form of remembrance where commerce and the Plan Cabanes market have a limited role.

Many of the antiques vendors who are now set up in the Plan Cabanes plaza have lived in the area for some time. During talking-while-walking tours through the streets to the west of the plaza, they told stories of informal movie theatres in back gardens, crafts and furniture markers, the local mechanic who used to be there but sold up, and the community theatre troupe which has become well regarded outside the neighbourhood. For many of the vendors, the word 'heritage' carried 
two distinct meanings. First, it denoted a real estate gimmick which presents the Plan Cabanes and surrounding streets as characteristic of a unique southern French character and atmosphere, and a selling point for the neighbourhood. And second, heritage spoke to a more personal sense of local history, tied to the artisans, community groups, performance artists, and migrant collectives which used to inhabit the spaces, and defined the everyday experience of the neighbourhood. One book vendor told stories of celebrating football victories in the Plan Cabanes after the produce market packed up. Many of the antiques vendors did their shopping in the plaza and emphasize the noisy sociability of the space, others explained that their children used to be students in the local school. For many the urban landscape - houses, storefronts, facades, markets, plazas, and parks - trigger personal stories, nostalgia, and memories of a close-knit community which many argued has started to disintegrate under the pressure of redevelopment.

If, as Halbwachs (1992) argues, memory is important to holding communities together, then the disparate memories surrounding the Plan Cabanes are certainly capable of dividing (Tyner et al., 2014). In view of the diverse stories told by residents, vendors, and market goers - of migration, resettlement, garden farmers selling at market, $19^{\text {th }}$ century military heritage, and local crafts and artisan networks - the Plan Cabanes carries a range of meanings, and it is hard to pin down a singular, definitive plaza and neighbourhood identity. Yet a coherent sense of identity is precisely what the heritage-led urban regeneration program seeks to achieve. The relocation of the diverse produce market in favour of French antiques is a step in the process of re-organizing the neighbourhood in a new image, and one which displaces narrative economies (Hoskins, 2010) in favour of an institutionalized view of history (Alderman \& Inwood, 2013). As Blokland (2009) notes, the ability to shape political discourse is an offshoot of the capacity to define collective memory. In this sense the relocation of a market has repercussions beyond the shifting of vendors and goods from one plaza to another: it breaks one chain of community memories tied to the Plan Cabanes plaza, and simplifies the diversity of histories in the area by reducing the types of activities, spaces, and materialities which can be categorized as 'heritage'.

\section{Materiality and plaza memories:}

In an instance where the articulation of local history and process of remembering have produced contested identities for the Plan Cabanes and surrounding neighbourhoods, the question of what sort of market to install in the plaza is a challenging topic. The shift from a produce to an antiques market is tied to a particular vision of how public space should be used. The role of the municipality in carefully organizing the re-development of the plaza, and an insistence on introducing a different type of commerce, suggests a desire to re-imagine this emblematic site. Local memory is woven into the process: the antiques market, as I will argue below, is linked to a particular cultural setting, one that seeks to emphasize specific forms of local heritage. 
Over several weeks of interviews and conversations with the antiques market vendors, I inquired about the relocation process - and the vendors' views on why city hall specifically sought out an antiques market. In an on going conversation with a book vendor, Pauline, we discussed the meaning of books versus produce, and she explained that the antiques market was 'cultural animation', a unique form of public space performance. She explained:

Beh, it's, it's cultural because we, we, we are defending heritage as well. We, the, I don't know if our trade will last forever but for the moment (pause) we are all the same defending, we are defending French heritage. Often we sell French books, eh, paintings, well, all the things that are antique are after all, eh, they were, eh, designed, created in France.(Pauline, book dealer, Plan Cabanes)

Dealing in antiques and books is both a commercial venture and a process closely tied to French identity making. The sale of French books, as Pauline suggests, is a cultural act and through this it defines the Plan Cabanes plaza as a French cultural space. While the neighbourhood might have a variety of identities and memories, the emblematic space of the neighbourhood is being deliberately tied to a very select reading of this history. If, as Pauline suggests, antiques represents French heritage, the creation of this market supports the notion that this is a neighbourhood worthy of a heritage designation.

In conversation with Lucien, it became clear that the ability to take part in the sale of French books and antiques is seen to require a certain cultural background. When asked why he chose to be a book seller rather than deal in antiques, Lucien explained:

What was easier for me to sell wasn't porcelain, ceramic, because that requires a culture, a knowledge that is very, very detailed, eh, of all the ateliers and all the styles. [...] I don't come from a bourgeois background where we deal with porcelain from Limoges [an area in France known for quality porcelain], that, well, as if we had some at home. [...] In contrast books, I know. Not all because it is impossible to know everything but I had a base, eh, cultural, well, I had knowledge, eh, of books because of their content more so than their, their form. If you wish that which I had to learn was, eh, about binding, it was, the history of books, the, the, the first editions, the first prints, etcetera. (Lucien, book dealer, Plan Cabanes)

In Lucien's explanation books and antiques are cultural and class products. With echoes of Bourdieu's (1984) notion of distinction, antiques such as porcelain, ceramics, furniture, linens and cloth, are tied to particular socio-cultural milieu. Lucien's decision to take up book vending rather than antiques is tied to what he perceives as his lack of knowledge to effectively deal with bourgeois material culture. Books, with their well marked provenance and more easily categorized value, are a form of commerce which can be learnt through studying. Yet, even 
book vending requires what Bourdieu (1984) may term class tastes - or, the ability to penetrate closed information networks. Asked how she learned book vending, Pauline explains:

I have visited many museums with books in them, I have consulted many ancient books, many libraries. Also the large selling salons, when there are notable books being sold. If there are sales, very notable sales, then it is enriching. [...] It wasn't obvious at the beginning because you are setting off in a milieu where you are not known, and so you have to find your own path. (Pauline, book dealer, Plan Cabanes)

It is through access to the closed environs of salons and auctions that Pauline acquired much of her knowledge about rare and ancient books, and thus ability to separate out the more banal items sold at the Plan Cabanes market from the more rare items she travels to Paris to sell. Creating a career out of this trade requires constant triage, knowledge of the other players, and access to the information networks that shape valuations. Pauline's comments, along with Lucien's, suggest that book vending is an activity that requires a broad knowledge of French literary and cultural heritage. Part of this is evident in the vocabulary used to describe the items on sale: what I may call 'books' the vendors call 'works', or sometimes 'cultural works'.

Amongst the antiques vendors the notion of background is equally important, even if the term 'bourgeois culture' is less often dropped into conversation. I asked Guillaume to explain the difference between a flea market vendor and an antiques market vendor, and he argued that they were not at all the same thing:

Between the '50s and today if you want, it's just used goods. It's not antiques it's used goods, it's flea market goods. Voilà [...]In reality, how can I explain it to you, it's, it's the quality and the, there (pointing to a vase) I have an object that is the difference, in my opinion. (Guillaume, antiques vendor, Plan Cabanes).

The object in this case was a 1940s vase and while my untrained eye could not spot the difference between this 'quality' item and what Guillaume termed 'used goods', for a collector the small marks at the base of the item, the colour, shape, and state of the object are telling signs. Guillaume further explained that antiques can be traced, and that they represented what he termed 'authentic' French culture rather than mass-produced consumer goods. It would seem that massmarket 'goods' rarely qualify as cultural 'objects' - the difference accentuated by Guillaume centering on notions of value that extend beyond the monetary worth of an item.

The antiques and book vendors, sitting together for a game of Scrabble one afternoon, outlined the requirements for joining their market. As a start, all vendors must be professionals: either part of an association which brings together recognized antiques and book vendors, or carrying the correct permits to 
deal in antiques. They must be, in other words, pre-approved by the same closed networks which Pauline and others turn to for information on key book sales. Vendors must also be prepared to undergo an 'authenticity' check, meaning an accredited antiques dealer from a nearby store can be called in to verify whether an item is truly antique, or simply a used good. The threat of fake antiques hung over the group with fears of their professional standing being questioned, and the reputation of this newly established market crashing in the process.

Two other terms enter the discussion through the above quotes: quality and authenticity. With respect to food markets and farmers' markets the dual designation of quality and authenticity has been considered in some detail (Dupuis \& Goodman 2005), with the notion of quality in food seen to emanate from the social and cultural context of production (Murdock et al., 2000) with links to place designations (Leitch, 2003) which in turn produce authentic products by reference to seemingly unique production methods, histories, and symbolic values (Stiles et al., 2011). The notions of 'authentic' seep into studies on antiques as well, with Jones and Alderman (2003) and Michael (2002) arguing that 'quality' antiques commerce has been used as a revitalization tool for tourism-dependent communities. Focusing on the redevelopment of the historic centre of Genoa, Italy, Guano (2006) argues that the installation of new antiques and craft stands in the city was used as a cultural redevelopment tool to alter the social and economic makeup of the area. The result is a new Genoa where the lived space of the historic city centre has been re-imagined as site of bourgeois culture, rather than the gritty, sometimes dilapidated place which has preceded the regeneration project.

Antiques, in other words, are closely tied to class tastes, and as Guano goes on to explain "Genoa's transformation could succeed only if renovation of the built environment was to be integrated with a change in the spatial practice and urban imagery of Genoa's publics"(2006, p.110). Zukin (2008) outlines a similar intersection of ethnic and class politics in New York City, as does Till (2005) in terms of redevelopment and gentrification in Berlin. The move from produce to antiques in Montpellier is part of a wider shift to actively re-imagine the Plan Cabanes neighbourhood. Particularly in an instance where French national and regional identity is closely tied to material cultures (Terrio, 2000), the introduction of antiques and books can be seen to emphasize certain forms of local heritage and memory over others.

\section{Public space and empty memories:}

The dance of memory and local history recounted in the previous sections labels the Plan Cabanes as a multi-faceted neighbourhood, a site of varied identities and communities. The discussion of antiques market materiality indicates that a deliberate shift in neighbourhood image and usage is being envisioned for this area, with a different form of public space usage. The memories and histories of vendors and users who self-identify as North African necessarily intersect with the stories of other groups, making it difficult to have a clear cut vision of 'us' and 'them'. Yet for many vendors, shopkeepers and market goers the relocation of the 
Marché du Plan Cabanes is viewed in a specific light: not just a market relocation, but a community disrupted, and an important presence removed from Montpellier's public space.

France is formally an ethnic-blind country: the definition of citizenship centres on republican notions of liberté, égalité, fraternité, articulated in a way that leaves little space for ethnic or cultural diversity (Dikeç, 2007). To become a citizen you effectively erase your past (Jugé \& Perez, 2006), adopting not only a language but also a cultural behaviour that ensures assimilation into the public sphere (cf. Weil, 2010). While this ethnic-blind republican model is intended to ensure that everyone is equal by removing obvious points for discrimination, in reality it can have the opposite effect. As Simon (2003) notes, making different cultural practices disappear also makes those of different ethnic backgrounds invisible, both in terms of their absence in official statistics and their inability to claim a culturally different share of public space. This leads to instances where concentrations of those perceived to be immigrants is seen as problematic (Wacquant, 2008), and prompts increased state interventions in "re-moralizing the public sphere" (Jennings, 2000, p.596) to ensure that it conforms to republican ideals.

The redevelopment of the Plan Cabanes, where a diverse market has been replaced by one intertwined with nuanced visions of French heritage and identity, speaks to these processes. With the public sphere seen as symbolic of French identity and heritage, the creation of homogeneous public spaces encapsulating republican ideals would leave little room for French citizens of diverse background to stake a claim to public space.

I asked a number of participants to outline how the plaza and their relationship with it has changed through the shifting of the produce market away from the Plan Cabanes. In conversation with informants who self-identify as North African and those who self-identify as French, we circled around the meaning of being French, the role of the plaza, and how the removal of the produce market affected local memories and communities. In conversation with Julie, an antiques vendor in the new Plan Cabanes and long time visitor to the relocated produce market, she explained what the plaza looked like before redevelopment began:

We can't recognize it (the new Plan Cabanes). Meaning, ok, it's paved and redone. It's a site that, how to explain, sites keep their memories. They are guardians of memory, the sites. But this plaza, if you wish, when there were people here it was the people whom I found interesting. The pla-, in reality it was the people who animated the plaza. So you see the actual physical plaza, I don't have any memories of that. [...] By contrast now the plaza itself, we are now obliged to look at it. The plaza is completely redone. It's been renewed. Empty. Almost empty of meaning. (Julie, antiques vendor, Plan Cabanes) 
For Julie, the pre-relocation plaza impressed users through the levels of social and commercial activity and interaction, rather than the physical components of stones, benches, fences, and trees. That the Plan Cabanes is viewed as a site that holds memories, and that these memories have been lifted through relocation, leaving the site empty, meaningless, and void, is a significant point. The Plan Cabanes has, effectively, been derailed as a lieux de mémoire and its spirit drained.

In conversation with Damya, a community leader, I asked him to describe the transformation and relocation as he saw it. He emphasized that there were used to be many more elder men, migrants from Morocco, Algeria and Tunisia in the 1960 s and 1970s, who used to walk amongst the stands and chat with the vendors. Damya noted that he had ample opportunities to join them, and pointed out two elder men sitting on a bench in the Plan Cabanes, noting that most do not come this way anymore. He lamented this loss, saying that it was important for the men to be there, but also for the rest of us to remember how they got there. He told several stories he has heard from his parents, of moving to France, and the Algerian wars, and then remarked that the plaza is void of meaning. In these discussions Damya built the types of narrative Hoskins (2010) and Carter et al. (2014) view as important to linking memory to landscape, drawing on the spaces of the Plan Cabanes to prompt recollection of migration and resettlement. He found that the Plan Cabanes was not just empty, but drained of the socio-cultural milieu that made it relevant. In his view the memory of Algerian migration has been wiped from this public space. He explained:

It was, I think that it was a visible market, very visible which attracted a lot of people and it was largely of, it was immigrant populations. [...] In Paris they did the same thing with Barbès (an ethnically diverse neighbourhood of Paris). Ok Barbès is still there but it has changed. And here they have done the same thing. In Nice they did the same thing. The old centre of Nice it was, there was a neighbourhood that was used mainly by Maghrebin. In the same way they lifted the market. All of a sudden there was no more market. [...] There is no longer anyone who comes here (Plan Cabanes). I think that it was good before. I think it was the desire of city hall that it was their desire to hide the, to simply hide the immigrants, that's the term. (Damya, business owner, Plan Cabanes)

From Damya's perspective, the relocation of the produce market from the Plan Cabanes centres on a municipal wish to remove a visible immigrant presence from a key urban site. The process is seen to erase a certain memory of immigration, of the French occupation of Algeria into the 1960s, and the extensive migrant trajectories of the 1960 s and 1970s that so fundamentally changed France's urban and social makeup. The selection of antiques as the replacement market is, in this context, highly politicized and a form of redevelopment that seeks to infuse a more 'valued' form of commerce into the 
plaza. The antiques market fits in precisely because it is tied to French national heritage, French identities, and French cultural traditions - a set of cultural values that mirror visions of the Plan Cabanes as a protected $19^{\text {th }}$ century architectural heritage.

I raised these points in interviews with municipal actors, and found limited willingness to engage with questions around ethnicity, identity, and public space usage. Some contacts argued that outdoor markets were by their very nature mobile, and so the relocation of one food market was nothing extraordinary. Others argued that with the Plan Cabanes neighbourhood being tied to the historic-city centre, it no longer made sense to have such a large commercial space in that location. The relocation of the produce market and establishment of an antiques market were frequently couched in terms of a desire to pare-down commercial activity in the neighbourhood: the produce market had up to four times the number of vendors currently present in the antiques market. As one contact explained, the produce market had become, in the eyes of the municipal team, simply too large:

The market which took place in the Plan Cabanes (the produce market) had, had evolved in a sense which did not suit us (municipality) completely. Because it was, eh, it was no longer only a local market, a local food market, it had become more or less a wholesale market. [...] It was a type that we didn't want to see being developed in that place [...] And so we asked ourselves, do we move it back or not? And it was eventually decided that, eh, we couldn't take the risk that the market developed once again in, in the other sense, on the Plan Cabanes. (Interviewee 1, Montpellier urban redevelopment team)

The decision to set up an antiques market was, for municipal contacts willing to comment on the topic, seen as a logical conclusion for a heritage-protected neighbourhood: there are very few other antiques and book markets in the city, and the creation of a new one in the Plan Cabanes was envisioned as a way of drawing in new users, shoppers, and visitors to bolster the redeveloped neighbourhood. The decision also mirrored the use of the antiques trade as a redevelopment tool in Italy (Guano, 2006) and the USA (Jones \& Alderman, 2003). Yet Damya, along with other local shopkeepers and market vendors who identify as Berber, Kabyle, Algerian, Moroccan or Tunisian, did not view this as a battle lost. Speaking about these events openly and making the relocation of the Plan Cabanes produce market a media spectacle, they consistently challenged both the redevelopment process and the establishment of the new antiques market.

In a turbulent conversation with Abdul, a community leader, the sense of injustice and anger at the market relocation was palpable. I asked Abdul about the redevelopment, his thoughts on the new Plan Cabanes, the notion of heritage protection, and why an antiques market may have been installed. He situated the relocation into broader national discourses on immigration, and in particular 
ongoing debates about a national crisis of identity brought on by the presence of too many immigrants, too many culturally unassimilated migrants, and too many suburban ghettos that mar the image of France (Weil, 2010). He explained, with reference to the North African community in Montpellier:

Today, alright, we (North African migrants). We like this country, it's a good country, but I find that all the same there are some imbeciles who are running things, they must start to understand. I will call them out. Who, they must start to understand, they must respect us, they must respect us. We didn't come on our own. I think. We came because they asked us to come. Ok. We worked. We are continuing to work, we pay our taxes like everyone else, and they must respect us. [...] There must be a minimum of respect towards others. A minimum of respect. They must not take us like nothing, we are not shit. They must view us as equals, like everyone else, like everyone else. [...] And here (Plan Cabanes) they don't respect us. They take decisions, they run meetings, they take decisions, and they don't even invite us. (Abdul, business owner, Plan Cabanes)

The relocation of the produce market was, in this view, a function of broader political trends that undermined the role and position of immigrants and French citizens of North African origin. The idea that migrants did not arrive on their own but were rather part of a national immigration drive is echoed in Abdul's comments. He is not asking for access to public space, but rather articulating his right to it, all the while arguing that the process of market relocation has extinguished that right in central Montpellier. The importance of the Plan Cabanes plaza as a site of North African-French identities is paramount, and the shifting of produce vendors is seen as a sign of disrespect and deliberate erasure from public space. The limited involvement of vendors and local shopkeepers in the market relocation process - echoed by other research participants heightens this sense of displacement and exclusion. By outlining what has been lost through the redevelopment of the plaza, Abdul, along with the respondents above, also focus on the cultural and social meaning of the plaza: as a site where Montpellier's North African immigrants were visible, as a public reminder of the colonial period, and most of all as a site where a diversity of residents were permitted access to the city and the right to occupy public space. The Plan Cabanes is empty space not only because it is devoid of animation and usage, but because it is a lieux de mémoire that is being erased, a site of forgetting, one where cultural identities are actively being removed.

\section{Conclusion:}

This article examines the links between memory, identity and public space within a French context. As demonstrated in debates over Montpellier's Plan Cabanes plaza, disputes over whose memories are materially represented in the city - who is viewed as forming local heritage - influences who is recognized as a social and 
political actor capable of shaping the public sphere. The stories of Plan Cabanes users highlights the complexity of meanings attached to this plaza, and the particular importance of this site for sustaining Montpellier's North African community. The plaza's function as a commercial and cultural hub, and the sociability it encouraged, made visible the city's diversity, thereby inserting histories of arrival and resettlement into the urban fabric. Personal stories of migration were therefore anchored to a specific place, giving those stories "material legitimacy" (Carter et al., 2014, p.549), a process disrupted through the relocation of the North African market and the start of neighbourhood urban renewal. The establishment of an antiques market in the Plan Cabanes was, as many participants argued, a symbolic act of re-imagining public space as representative of a dominant narrative of French history (Stora, 2003).

To borrow from Klein's (1997) vocabulary, the Plan Cabanes is a place that at once exists and is absent: the physical space is there, in terms of the stones and benches that form the plaza; yet the cultural meaning and milieu have moved, shifted, and been hidden from view. In an instance where street furniture and landscapes encapsulates certain memories (Till, 2005) and historical narratives are tied to place making (Blokland, 2009), the displacement of the North African market is a form of physical and cultural erasure. In view of this, the heritageprotection-led redevelopment of the Plan Cabanes speaks to a desire to simplify the local urban landscape, and in turn, pare down the forms of public space usage. The removal of certain socio-cultural identities highlight the seeming noncompatibility of heritage policies and ethnic diversity, and further emphasize the absence of colonial histories from French heritage landscapes (Ross, 1996; Stora, 2003; Legg, 2005). The resulting contestation over the plaza's future intersect with broader French debates on immigration, identity, and cultural belonging, with the transfer of this ideology to the public sphere leaving little room for the recognition of ethnic and cultural difference (cf. Weil, 2010), and effectively removing the capacity of certain groups to claim social rights to the redeveloped neighbourhood landscape.

Acknowledgements: Particular thanks to Peter Jackson and Paul White for their comments on earlier versions of this paper. Many thanks to the three anonymous reviewers for their helpful remarks, and to Robert Wilton for editorial guidance. I am especially grateful to all the participants who shared their thoughts and led me on many walking tours through Montpellier.

\section{References:}

Alderman, D. H., \& Inwood, J. (2013). Landscapes of memory and socially just futures. In The Wiley-Blackwell Companion to Cultural Geography (pp. 186197). Malden, MA: Wiley-Blackwell.

Amin, A., \& Thrift, N. (2002). Cities: Reimagining the urban. Cambridge: Polity Press. 
Amiraux, V., \& Simon, P. (2006). There are no minorities here: Cultures of scholarship and public debate on immigrants and integration in France.

International Journal of Comparative Sociology, 47, 191-215. doi: 10.1177/0020715206066164

Anderson, J. (2004). Talking whilst walking: A geographical archaeology of knowledge. Area, 36, 254-261. doi: 10.1111/j.0004-0894.2004.00222

Ashworth, G., \& Tunbridge, J. (1999). Old cities, new pasts: heritage planning in selected cities of Central Europe. GeoJournal, 49(1), 105-116.

Azaryahu, M. (1996). The power of commemorative street names. Environment and Planning D: Society and Space, 14, 311-330. doi: 10.1068/d140311

Barone, S. (2010). Le projet Grand Coeur. In J.P. Volle, L. Viala, E. Négrier, \& C. Bernié-Boissard (Eds). Montpellier: La ville inventée (pp. 92-109). Marseille: Edition Parenthèse / Gip Epau.

Benhamou, F. (2014). Neoliberalism and French heritage policy in the context of globalization. Heritage \& Society, 7, 47-56. doi:

10.1179/2159032X14Z.00000000018

Besombes-Vailhe, P. (1995). Emergence des 'faites de frontières culturelles' autour 'd'un espace communautaire' maghrébin: le quartier du plan Cabanes à Montpellier. Etude pour la compte de la Mission du Patrimoine.

Blokland, T. (2009). Celebrating local histories and defining neighbourhood communities: Place-making in a gentrified neighbourhood. Urban Studies, 46, 1593-1610. doi: 10.1177/0042098009105499

Bonnett, A., \& Alexander, C. (2013). Mobile nostalgias: Connecting visions of the urban past, present and future amongst ex-residents. Transaction of the Institute of British Geographers, 38, 391-402. doi: 10.1111/j.1475-5661.2012.00531.x

Bourdieu, P. (1984). Distinction: A social critique of the judgement of taste. Cambridge, MA: Harvard University Press (this edition 2002).

Buck-Morss, S. (1991). The dialectics of seeing: Walter Benjamin and the Arcades Project. Cambridge, MA: MIT Press.

Carter, P., Butler, D. L., \& Alderman, D. H. (2014). The house that story built: the place of slavery in plantation museum narratives. The Professional Geographer, 66(4), 547-557. http://doi.org/10.1080/00330124.2014.921016

Chivallon, C. (2001). Bristol and the eruption of memory: making the slavetrading past visible. Social \& Cultural Geography, 2, 347-63. doi:

10.1080/14649360120073905 
Cochrane, A. (2006). Making up meaning in a capital city: Power, memory and monuments in Berlin. European Urban and Regional Studies, 13, 5-24. doi: 10.1177/0969776406060827

Degen, M. M., \& Rose, G. (2012). The sensory experiencing of urban design: the role of walking and perceptual memory. Urban Studies, 49, 3271-87. doi: 10.1177/0042098012440463

Dikeç, M. (2007). Badlands of the republic: Space, politics, and urban policy. Oxford: Blackwell Publishing.

Dupuis, E.M., \& Goodman, D. (2005). Should we go "home" to eat?: Towards a reflexive politics of localism. Journal of Rural Studies, 21, 359- 371. doi: 10.1016/j.jrurstud.2005.05.011

Edensor, T. (2008). Mundane hauntings: Commuting through the phantasmagoric working-class spaces of Manchester, England. Cultural Geographies, 15, 313-333. doi: 10.1177/1474474008091330

Enjelvin, G., \& Korac-Kakabadse, N. (2012). France and the memories of 'others': The case of the Harkis. History \& Memory, 24(1), 152-77. doi:10.1353/ham.2012.0003.

Faure, P. (1998). Un quartier de Montpellier: Plan Cabanes, étude ethnologique. Paris: L'Harmattan.

Gillot, L., Maffi, I., \& Trémon, A.-C. (2013). 'Heritage-scape' or 'heritage-scapes'? Critical considerations on a concept. Ethnologies, 35(2), 3-29. doi:

doi:10.7202/1026546ar

Gravari-Barbas, M., \& Veschambre, V. (2000). Patrimoine et environnement: Les territoires du conflit. Norois, 47(185), 3-5.

Guano, E. (2006). Fair ladies: The place of women antique dealers in postindustrial Italian city. Gender, Place \& Culture: A Journal of Feminist Geography, 13, 105-122. doi: 10.1080/09663690600573536

Halbwachs, M. (1992). On collective memory. (L.A. Coser, Trans.). Chicago: University of Chicago Press.

Harvey, D.C. (2014). Heritage and scale: Settings, boundaries and relations. International Journal of Heritage Studies, 1-17. doi:10.1080/13527258.2014.955812.

Hayden, D. (1997). The power of place: Urban landscape as public history. Cambridge, MA: MIT Press.

Hoelscher, S., \& D. Alderman. (2004). Memory and place: Geographies of a 
critical relationship. Social \& Cultural Geography, 5, 347-355. doi:

10.1080/1464936042000252769.

Hoskins, G. (2010). A secret reservoir of values: the narrative economy of Angel Island Immigration Station. Cultural Geographies, 17(2), 259-275. doi: http://doi.org/10.1177/14744474010363850

Hoskins, G. (2007). Materialising memory at Angel Island Immigration Station, San Francisco. Environment and Planning A, 39(2), 437-455. doi: http://doi.org/DOI:10.1068/a38174

Jennings, J. (2000). Citizenship, republicanism and multiculturalism in contemporary France. British Journal of Political Science, 30, 575-598.

Jones, K., \& Alderman, D. H. (2003). Antiques tourism and the selling of heritage in Eastern North Carolina. The North Carolina Geographer, 11, 74-87.

Jugé, T., \& M. Perez. (2006). The modern colonial politics of citizenship and whiteness in France. Social Identities: Journal for the Study of Race, Nation and Culture, 12, 187-212. doi: 10.1080/13504630600583387

Jurgens, J. (2012). Invisible migrants: memory and German nationhood in the shadow of the Berlin wall. In M. Silberman, K. Till \& J. Ward (Eds.), Walls, borders, boundaries: spatial and cultural practices in Europe (pp. 191-210). New York: Berghahn Books.

Klein, N.M. (1997). The history of forgetting: Los Angeles and the erasure of memory. London: Verso.

Lai, C. (2012). The racial triangulation of space: The case of urban renewal in San Francisco's Fillmore District. Annals of the Association of American Geographers, 102, 151-170. doi: 10.1080/00045608.2011.583572

Lefebvre, H. (1991). The production of space. (D. Nicholson-Smith, Trans). Oxford: Blackwell.

Lefebvre, H. (1996). The right to the city. Writings on cities. (E. Kofman \& E. Lebas, Trans). Oxford: Blackwell.

Legg, S. (2005). Contesting and surviving memory: Space, nation, and nostalgia in les lieux de mémoire. Environment and Planning D: Society and Space, 23, 481-504. doi: 10.1068/do504

Leitch, A. (2003). Slow Food and the politics of pork fat: Italian food and European identity. Ethnos, 68, 437-462. doi: 10.1080/0014184032000160514 
Linossier, R., Russeil, S., \& Zepf, M. (2004). Entre conflits et synergies: Renouvellement urbain et patrimonialisation. disP-The Planning Review, 40(159), 4-12. doi: 10.1080/02513625.2004.10556894

Lowenthal, D. (1985). The past is a foreign country. Cambridge: Cambridge University Press.

Mansvelt, J. (2010). Geographies of consumption: Engaging with absent presences. Progress in Human Geography, 34, 224-233. doi:

10.1177/0309132509339934

Melé, P. (2005). Conflits patrimoniaux et régulation urbaine. ESO Travaux et Documents, Espaces et SOciétés - UMR 6590, 51-57. Retrieved from:

http://assos.univlemans.fr/LABO/eso/TELECHARGEMENTS/revue/ESO 23/mele.pdf.

Michael, E. (2002). Antiques and tourism in Australia. Tourism Management, 23(2), 117-125.

Mitchell, D. (2003). The right to the city: Social justice and the fight for public space. New York: Guilford Press.

Murdock, J., T. Marsden, T., \& Banks, J. (2000). Quality, nature and embeddedness: Some theoretical considerations in the context of the food sector. Economic Geography, 76, 107-125. doi: 10.1111/j.1944-8287.2000.tboo136.x

Muzaini, H. (2013). Scale politics, vernacular memory and the preservation of the Green Ridge battlefield in Kampar, Malaysia. Social \& Cultural Geography, 14(4), 389-409. http://doi.org/10.1080/14649365.2013.777088

Nora, P. (1989). Between memory and history: Les lieux de mémoire. Representations, 26(Spring), 7-24. Retrieved from:

http://www.jstor.org/discover/10.2307/2928520?uid=3739448\&uid=2129\&uid $=2134 \&$ uid $=2 \& u i d=70 \&$ uid $=3737720 \&$ uid $=4 \&$ sid $=21106496241343$

O'Keeffe, T. (2007). Landscape and memory: Historiography, theory, methodology. In N. Moore \& Y. Whelan (Eds.), Heritage, memory and the politics of identity: new perspectives on the cultural landscape (pp.3-18). Aldershot: Ashgate Publishing.

Peckham, R. (2003). Rethinking heritage: Cultures and politics in Europe. London: I.B.Tauris.

Poirrier, P. (2003). Heritage and cultural policy in France under the fifth republic. International Journal of Cultural Policy, 9, 215-25. doi: http://dx.doi.org/10.1080/1028663032000119251

Poria, Y., \& Ashworth, G. (2009). Heritage Tourism - Current Resource for 
Conflict. Annals of Tourism Research, 36, 522-25. doi:

10.1016/j.annals.2009.03.003

Proust, M. (1913 / 1992). In search of lost time, volume 1: Swann's way. (D.J. Enright, Trans.). London: Vintage.

Rose-Redwood, R. (2008). From number to name: Symbolic capital, places of memory and the politics of street renaming in New York City. Social \& Cultural Geography. 9, 431-52. doi: 10.1080/14649360802032702

Ross, K. (1996). Fast cars, clean bodies: Decolonization and the reordering of French culture. Cambridge, MA: MIT Press.

Simon, P. (2003). France and the unknown second generation: preliminary results on social mobility. International Migration Review, 37, 1091-1119. doi: 10.1111/j.1747-7379.2003.tboo171.x

Stevens, M. (2007). Museums, minorities and recognition: Memories of North African in contemporary France. Museum and Society, 5, 29-43. Retrieved from: http://www2.le.ac.uk/departments/museumstudies/museumsociety/documents /volumes/stevens.pdf

Stiles, K., Altiok, O., \& Bell, M. (2011). The ghosts of taste: food and the cultural politics of authenticity. Agriculture and Human Values, 28, 225- 236. doi: 10.1007/s10460-010-9265-y

Stora, B. (2003). Guerre d'Algérie: 1999-2003, les accélérations de la mémoire. Hommes \& Migrations 1244, 83-96. Retrieved from http://www.hommes-etmigrations.fr/index.php?/numeros/francais-et-algeriens/1528-Guerre-d-Algerie1999-2003-les-accelerations-de-la-memoire

Terrio, S.J. (2000). Crafting the culture and history of French chocolate. Berkeley: University of California Press.

Till, K.E. (2005). The new Berlin: Memory, politics, place. Minneapolis: University of Minnesota Press.

Tyner, J., Inwood, J., \& Alderman, D. H. (2014). Theorizing violence and the dialectics of landscape memorialization: a case study of Greensboro, North Carolina. Environment and Planning D: Society and Space, 32(5), 902-914.

Veschambre, V. (2007). Patrimoine: Un objet révélateur des évolutions de la géographie et de sa place dans les sciences sociales. Annales de Géographie 656, 361-81. doi: 10.3917/ag.656.0361

Wacquant, L. (2008). Urban outcasts: A comparative sociology of advanced marginality. Cambridge: Polity Press. 
Waterton, E., \& Smith, L. (2010). The Recognition and Misrecognition of Community Heritage. International Journal of Heritage Studies, 16, 4-15. doi: 10.1080/13527250903441671

Weil, P. (2010). How to be French: Nationality in the making since 1789. Translated by C. Porter. Durham, North Carolina: Duke University Press.

Wertsch, J. 2009. Collective memory. In P. Boyer \& J. Wertsch (Eds). Memory in mind and culture, (pp. 117-137). Cambridge: Cambridge University Press.

Zukin, S. (2008). Consuming authenticity: from outposts of difference to means of exclusion. Cultural Studies, 22, 724-748. doi: 10.1080/09502380802245985

\section{Figure captions:}

Figure 1: The renovated Plan Cabanes plaza. 